\title{
JUURNAL_RU
}

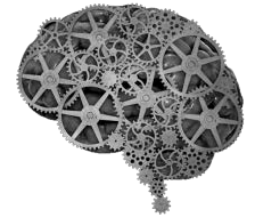

COMPANY GROUP "INTELLEKT"

\author{
Черемных Ю.А. \\ Иркутский Государственный Университет. Институт филологии, иностранных \\ языков и медиакоммуникации \\ Иркутск, Россия
}

doi: 10.18411/lj2016-9-1-13

idsp 000001: lj2016-18-1-13

\section{Сравнительный анализ развития высшего профессионально-технического образования в КНР и СССР в период с 1949-1960 г.}

На сегодняшний день российско-китайское сотрудничество в образовательной сфере проходит в самых различных направлениях: зарубежное и отечественное востоковедение и регионоведение [2], изучение вопросов философии [4], аксиологии[12], социологии[11], культуры[14] [15], экономики[8], истории языка[1] [3], языковой картины мира[10], ономастики и антропонимики[13] и других. В связи с тем, что высшее профессиональнотехническое образование на этом этапе развития мало изучено, тема остается открытой на сегодняшний день.

Советское и китайское профессионально-техническое образование претерпело ряд изменений в течение периода с 1949 по 1960 год. В 1949 году происходит зарождение профессионально-технического образования как отдельной структуры в высшем образовании, как СССР, так и КНР. В послевоенный период в СССР имелись проблемы в промышленной и экономической базах страны, в связи с этим возникает потребность в технических кадрах, которые в свою очередь смогли бы поспособствовать процессу восстановления народного хозяйства. В КНР резкая смена власти привела к возникновению тяжелой ситуации в стране, у правительства появилась необходимость в помощи от советского государства. В этот период времени из СССР в КНР было направлено огромное количество квалифицированных технических кадров. 
С 1949 по 1960 гг. СССР и КНР вышли на новый уровень сотрудничества. В 1950 году между двумя странами был подписан договор «О дружбе и взаимопомощи».

На фоне роста уровня профессионально-технического образования, как в КНР, так и в СССР, были проведены реформы. Например, в 1953 году правительство КНР издало указ, в котором были чётко прописаны критерии деления профессионально-технических учебных заведений на мелкие структуры: средне-специальные техникумы, профессиональные техникумы и высшие учебные заведения.

Если в рассматриваемый период времени правительство КНР больше внимания уделяло на дифференцирование высших учебных заведений, то в СССР, напротив идёт объединение структуры. Так, существовавшие на 1949 год советские школы фабрично-заводского ученичества были реорганизованы в профессионально-технические училища. Реорганизация была проделана в связи с тем, что в этот период роль технического образования возрастало, обучение в ПТУ было престижнее по сравнению с ФЗУ.

В СССР 19 сентября 1952 года вышел документ «Об учебных программах и режиме в высшей школе и техникумах». В связи с этим были разработаны новые учебные планы, которые позволяли внести новшества в систему преподавания в технических училищах. Развитие профессиональнотехнического образования в СССР было на уровень выше, чем в КНР, поэтому китайское правительство заимствовало некоторые образовательные программы обучения у советского преподавательского состава. Это указывало на то, что СССР и КНР являлись стратегическими партнёрами не только в политической сфере, но и в гуманитарной, технической сферах.

Таким образом, на фоне развития промышленной базы как в СССР так и в КНР возникала потребность в технических кадрах, которые смогли бы на профессиональном уровне обслуживать технические объекты (заводы, фабрики, машинное оборудование). На 1949 год по состоянию развития профессиональнотехнического образования в КНР имелось 569 среднетехнических учебных заведений, а в СССР - 1030, что в свою очередь не удовлетворяло потребности восстановления китайского и советского народного хозяйства. В СССР происходит реорганизация средне-специальных технических учебных 
заведений, направленная на создание системы высшего профессиональнотехнического образования. В КНР, так же как и в СССР, профессиональнотехническое образование играло значительную роль. Помимо среднеспециальных профессиональных техникумов открывались высшие учебные заведения, где ключевую роль играло заимствование советского опыта в организации профессионально-технического обучения.

На данном этапе развития, Россия и Китай плотно сотрудничают в области высшего образования[6], осуществляя всевозможные международные обмены[9], разрабатывая новые курсы и дисциплины[5], учебные пособия[7]. Данная сфера является перспективной для поиска дальнейших направлений взаимодействия двух стран.

\section{Литература:}

1. Воронина О.Ю. О модели описания истории языка с идеографическим типом письма (на примере работы ПаньЮньчжуна) // Языковое образование в аспекте взаимодействия культур: Материалы V международной научно-практической конференции. 2013. С. 11-19.

2. Готлиб О.М., Назаров В.В., Кагарманова А.Ф., Баринкова А.В. Зарубежное и отечественное регионоведение и востоковедение: вгляды И.М. Ошанина на теории китайской письменности // Успехи современной науки и образования. 2016. Т. 3. № 7. С. 147-152.

3. Ерофеева О.Н. Об эволюции классификаторов в классическом древнем китайском и среднекитайском языке // Культуры и языки стран дальнего востока: изучение и обучение: Международная научно-практическая конференция (Иркутск, 16-17 октября 2014 г.). 2014. С. 127-133.

4. Корешкова Ю.О., Смолова Д.М., Воронина О.Ю. К вопросу об идеях легизма как ресурсе регулирования общественных отношений в современном Китае // Успехи современной науки и образования. 2016. Т. 3. № 7. C. 153-155. 
5. Кобжицкая О.Г. К вопросу о терминологии и понятийном аппарате в курсах по истории и культуре Востока // Преподавание истории и культуры стран Азии в средней и высшей школе России: исторический опыт и современные проблемы: материалы Всероссийской научнопрактической конференции с международным участием. СФУ. 2007. С. 68-72.

6. Кремнёв Е.В., Шишмарёва Т.Е., Готлиб О.М. Опыт международного сотрудничества кафедры китаеведения ИГЛУ в рамках работы над новыми учебно-методическими комплексами по обучению китайскому языку // Сборник докладов Форума ректоров вузов Дальнего Востока и Сибири РФ и северо-восточных регионов КНР (на русском и китайском языках) 2012. С. 57-59.

7. Кремнёва Т.А., Ван Ланьцзюй. Китайский язык. Начальный уровень. Иркутск, 2015. 180 с.

8. Кумялова О.В. Некоторые аспекты российско-китайских торговых отношений // Россия и Китай: История и перспективы сотрудничества: материалы VI международной научно-практической конференции. Институт Конфуция в БГПУ. 2016. С. 265-267.

9. Макеева С.Б., Адилханян Н.Л., Кошель А.М. К вопросу об академическом обмене как одной из перспектив российско-китайского сотрудничества в образовательной сфере // Успехи современной науки и образования. 2016. Т. 1. № 7. С. 188-190.

10. Стефановская С.В. Способы семиотизации звукового мира (на материале языка с идеографической системой письма).диссертация на соискание ученой степени кандидата филологических наук. ИГЛУ. Иркутск, 2012. 199 c.

11. Терехова Н.В. Американская массовая культура в Китае: за и против // Философия и будущее цивилизации Тезисы докладов и выступлений IV Российского философского конгресса. 2005. С. 409-410. 
12. Хадеева А.П. Китайская ритуальная символика в аксиологическом аспекте // Культуры и языки стран дальнего востока: изучение и обучение: Международная научно-практическая конференция (Иркутск, 16-17 октября 2014 г.). 2014. С. 251-261.

13. Хамаева Е.А. Антропонимы в ономастической системе мифологического типа. Диссертация на соискание ученой степени канд. фил.наук / ИГЛУ. Иркутск, 2012. 200 с.

14. Хо О.А. «Вино» 酒 как ритуал в культуре Китая // Культуры и языки стран дальнего востока: изучение и обучение: Международная научнопрактическая конференция (Иркутск, 16-17 октября 2014 г.). 2014. С. 282-290.

15. Шаравьева И.В. Понятие «вэнь» в культуре Китая. АзиатскоТихоокеанский регион: диалог языков и культур: Материалы II Международной научно-практической конференции. 2016. С. 233-236. 